\title{
FACTORS ASSOCIATED WITH JOB PERFORMANCE OF MIDWIVES AT COMMUNITY HEALTH CENTERS IN MOJOKERTO, EAST JAVA
}

\author{
Veterina Rizki Amalia'), Hanung Prasetya'), Bhisma Murti') \\ 1) Masters Program in Public Health, Universitas Sebelas Maret \\ ${ }^{2)}$ School of Health Polytechnics, Ministry of Health Surakarta
}

\begin{abstract}
Background: Midwives performance play an important role in reducing maternal and neonatal morbidity and mortality. The purpose of this study was to analyze factors associated with midwives performance in Mojokerto, East Jva, Indonesia.

Subjects and Method: A cross sectional study was carried out in Mojokerto, East Java, Indonesia. A sample of 200 midwives who worked in community health centers was selected randomly. The dependent variable was works performance. The independent variables were age, tenure, employment status, perceived financial compensation, social support, workload, and motivation. The data were collected by a questionnaire and analyzed by a multiple logistic regression run on Stata 13.

Results: Work performance in midwives increased with age $\geq 42$ years $(\mathrm{OR}=9.2 ; 95 \% \mathrm{CI}=$ 1.91 to $44.72 ; \mathrm{p}=0.006)$, tenure $\geq 18$ years $(\mathrm{OR}=4.5 ; 95 \% \mathrm{CI}=1.04$ to $19.46 ; \mathrm{p}=0.044)$, high perceived financial compensation $(\mathrm{OR}=10.65 ; 95 \% \mathrm{CI}=2.23$ to $50.97 ; \mathrm{p}=0.003)$, strong social support $(\mathrm{OR}=12.53 ; 95 \% \mathrm{CI}=2.59$ to $60.70 ; \mathrm{p}=0.002)$, low workload $(\mathrm{OR}=10.88 ; 95 \% \mathrm{CI}=$ 2.41 to $49.12 ; \mathrm{p}=0.002)$, and strong motivation $(\mathrm{OR}=13.52 ; 95 \% \mathrm{CI}=2.64$ to $69.21 ; \mathrm{p}=0.002)$. Work performance decreased with non civil servants $(\mathrm{OR}=0.071 ; 95 \% \mathrm{CI}=0.01$ to $0.55 ; \mathrm{p}=$ 0.011).

Conclusion: Work performance in midwives increases with age $\geq 42$ years, tenure $\geq 18$ years, high perceived financial compensation, strong social support, low workload, and strong motivation. Work performance decreases with non civil servants.
\end{abstract}

Keywords: work performance, financial compensation, midwives

\section{Correspondence:}

Veterina Rizki Amalia. Masters Program in Public Health, Universitas Sebelas Maret. Jl. Ir. Sutami 36A, Surakarta 57126, Central Java. Email: veterinarizki1@gmail.com. Mobile: +6281359016501 .

The $7^{\text {th }}$ International Conference on Public Health Solo, Indonesia, November 18-19, 2020 358 https://doi.org/10.26911/the7thicph.04.43 